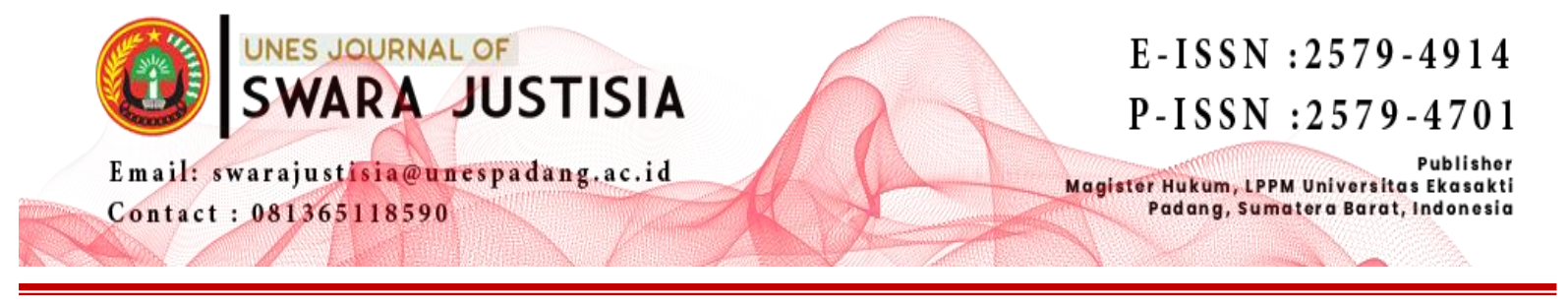

\title{
UPAYA PENANGGULANGAN TINDAK PIDANA PENANGKAPAN IKAN DENGAN BAHAN PELEDAK DI WILAYAH HUKUM POLRES KEPULAUAN MENTAWAI
}

\author{
${ }^{1)}$ Hendri, ${ }^{2)}$ Aji Wibowo \\ ${ }^{1)}$ IAIN Bukittinggi \\ Email: regamahendrik@gmail.com \\ ${ }^{2)}$ Fakultas Hukum Universitas Trisakti \\ Email: aji.wibowo@gmail.com
}

\begin{abstract}
Mentawai Islands Resort Police effort in overcoming the crime of fishing using explosives is in the form of socialization or counseling that is centered on the community in fishing villages indicated to carry out fishing activities using explosives. Conduct Routine Patrol which is carried out approximately 2 times a month and on important days. The obstacle of the Mentawai Islands Resort Police in an effort to tackle fishing crimes using explosives is the indecisive factor in the application of criminal sanctions against fishing criminals using explosives. because of economic demands. Another obstacle is the lack of community awareness of the environment, especially the marine environment, the lack of knowledge of the fishing community about the impact of the use of explosives in fishing.
\end{abstract}

Keywords: Countermeasures, Fishing, Explosives

\begin{abstract}
ABSTRAK
Upaya Polres Kepulauan Mentawai dalam penanggulangan tindak pidana penangkapan ikan dengan menggunakan bahan peledak adalah berupa sosialisasi Atau penyuluhan yang dipusatkan kepada masyarakat di desa desa nelayan yang terindikasi melakukan aktifitas penangkapan ikan dengan menggunakan bahan peledak. Melakukan Patroli Rutin yang dilaksanakan kurang lebih 2 kali dalam sebulan dan pada hari hari penting. Kendala Polres Kepulauan Mentawai dalam upaya penanggulangan tindak pidana penangkapan ikan dengan menggunakan bahan peledak adalah faktor tidak tegasnya penerapan sanksi pidana terhadap pelaku tindak pidana penangkapan ikan dengan menggunakan bahan peledak sering kasus hanya diselesaikan dengan pembuatan surat perjanjian dikarenakan faktor penyebab masyarakat menangkap ikan dengan bahan peledak hanya karena tuntutan ekonomi. Kendala lain adalah Kurangnya kepedulian masyarakat akan lingkungannya terutama lingkungan laut, kurangnya pengetahuan masyarakat nelayan akan dampak penggunaan bahan peledak dalam melakukan penangkapan ikan.
\end{abstract}

Kata Kunci: Penanggulangan, Penangkapan Ikan, Bahan peledak 


\section{PENDAHULUAN}

Negara Indonesia mempunyai panjang garis pantai sekitar 81,791 km, yang merupakan pantai terpanjang kedua di seluruh dunia, setelah Canada. Panjangnya perairan dangkal ini tumbuh subur dan tingginya keanekaragaman jenis organisme penghuninya. ${ }^{1}$ Organisme-organisme ini tersebar ke seluruh sub-sistem yang ada di ekosistem perairan pesisir laut tropis, di samping itu ekosistem tersebut diketahui juga mempunyai potensi yang sangat besar untuk menunjang produksi perikanan ${ }^{2}$ Sektor perikanan memiliki peranan yang penting dan strategis dalam pembangunan perekonomian nasional, terutama dalam meningkatkan perluasan kesempatan kerja, pemerataan pendapatan, dan peningkatan taraf hidup bangsa pada umumnya, nelayan kecil, pembudidaya ikan, dan pihak-pihak pelaku usaha di bidang perikanan dengan tetap memelihara lingkungan, kelestarian dan ketersediaan sumber daya ikan.

Pada Pasal 85 Undang-Undang Nomor 45 Tahun 2009 tentang Perikanan sebagai pembaruan atas Undang-Undang Nomor 31 Tahun 2004 tentang Perikanan diatur tentang tindak pidana perikanan berbentuk menangkap ikan menggunakan alat yang dapat merusak ekosistem.

Untuk dapat menanggulangi meluasnya penggunaan bahan peledak dalam melakukan penangkapan ikan di laut, maka perlu ditingkatkan penyuluhan hukum bagi masyarakat nelayan tentang bahaya dari akibat penggunaan bahan peledak tersebut. Walaupun penangkapan ikan dengan menggunakan bahan peledak adalah suatu perbuatan terlarang yang bertentangan dengan peraturan hukum yang berlaku, akan tetapi dalam kenyataannya di wilayah perairan Kabupaten Kepulauan Mentawai, masih sering terjadi penangkapan ikan secara illegal dengan cara menggunakan bahan peledak (bom ikan) oleh para nelayan.

Penangkapan ikan menggunakan bahan peledak akan mematikan ikan secara langsung, tetapi dapat pula membahayakan kesehatan manusia dan merugikan nelayan serta pembudidaya ikan. Apabila terjadi kerusakan sebagai akibat penggunaan bahan dan alat yang dimaksud, pengambilan keadaan semula akan membutuhkan waktu yang lama, bahkan mungkin mengakibatkan kepunahan ${ }^{3}$. Penggunaan alat penangkap ikan yang tidak sesuai dan yang sesuai dengan syarat atau standar yang ditetapkan untuk tipe alat tertentu oleh negara termasuk juga di dalamnya alat penangkapan ikan yang dilarang oleh negara. Pelarangan penggunaan alat penangkapan ikan dan/atau alat bantu penangkapan ikan diperlukan untuk menghindari adanya penangkapan ikan dengan menggunakan peralatan yang dapat merugikan kelestarian sumber daya ikan dan lingkungannya. Hal itu dilakukan mengingat wilayah pengelolaan perikanan Indonesia sangat rentan terhadap penggunaan alat penagkapan ikan yang tidak sesuai dengan ciri khas alam, serta kenyataan terdapatnya berbagai jenis sumberdaya ikan di Indonesia yang sangat bervariasi, menghindari tertangkapnya jenis ikan yang bukan menjadi target penangkapan.

\footnotetext{
${ }^{1}$ Daliyo et al., Pelestarian Sumber Daya Laut, Partisipasi Dan Kesejahteraan Penduduk Di Kawasan Pesisir (Jakarta: Leusercita Pustaka, 2011). Hlm. 1. 2009, hlm.17

${ }^{2}$ Supriharyono, Konvensi Ekosistem Sumberdaya Hayati, Cet,ke-1, Pustaka Pelajar, Yogyakarta,

${ }^{3}$ Suharto, Limbah Kimia dalam Pencemaran Udara dan Air, Andi Offset, Yogyakarta, 2011, hlm. 61
} 
Di Kepulauan Mentawai, kerusakan terumbu karang akibat bom ikan juga terjadi. Saat ini, sekitar 55\% terumbu karang di Kepulauan Mentawai telah rusak akibat bom ikan. Cara penangkapan ikan seperti ini telah merusak ekosistem yang ada di bawah permukaan laut, termasuk terumbu karang. Tidak hanya terumbu karangnya yang rusak, melainkan jutaan spesies biota laut yang unik bisa terancam akibat pemboman ikan itu. Khusus di wilayah perairan Kabupaten Kepulauan Mentawai banyak terjadi kasus penangkapan ikan dengan menggunakan bahan peledak.

Pelaku menangkap ikan dengan cara mencari lokasi yang banyak ikannya terlebih dahulu, kemudian pelaku membakar sumbu api bom ikan rakitan tersebut kemudian dilemparkan ke tempat berkumpulnya ikan, setelah meledak, pelaku kemudian menyelam untuk mengumpulkan ikan-ikan yang sudah mati karena terkena dampak dari bom tersebut.

Berdasarkan latar belakang pemikiran yang telah dipaparkan di atas, maka rumusan permasalahan adalah upaya Polres Kepulauan Mentawai dalam penanggulangan tindak pidana penangkapan ikan dengan menggunakan bahan peledak Dan Bagaimanakah Kendala Polres Kepulauan Mentawai dalam upaya penanggulangan tindak pidana penangkapan ikan dengan menggunakan bahan peledak.

\section{METODE PENELITIAN}

Spesifikasi penelitian adalah deskriptif analitis, dengan metode pendekatan yuridis normatif didukung yuridis empiris. Jenis data yang digunakan adalah data sekunder dan data primer. Data sekunder diperoleh dari studi dokumen dan studi kepustakaan. Data yang diperoleh kemudian dianalisa secara kualitatif.

\section{HASIL DAN PEMBAHASAN}

\section{A. Upaya Polres Kepulauan Mentawai Dalam Penanggulangan Tindak Pidana Penangkapan Ikan Dengan Menggunakan Bahan Peledak}

Salah satu bentuk tindakan eksploitasi hasil perikanan yang ilegal yaitu penggunaan bahan peledak atau yang dikenal dengan istilah "bom ikan" dalam menangkap. Penggunaan bahan peledak atau Bom ikan untuk menangkap pada prinsipnya merupakan suatu tindak pidana yang bertentangan dengan Pasal 84 dan Pasal 85 Undang-Undang No.31 Tahun 2004 Tentang Perikanan. Akibat dari tindakan pemboman ikan juga dapat merusak kehidupan ekosistem laut sehingga menghambat upaya konservasi dan perlindungan lingkungan laut termasuk perlindungan perikanan daerah. Menurut Muhamad Erwin, pencemaran pantai, sedimen yang tebal akibat penebangan hutan di hulu, penangkapan ikan dengan racun dan bom, penggalian batu karang, dan penangkapan ikan yang berlebihan di beberapa tempat juga mengancam keanekaragaman hayati pantai dan laut Indonesia yang tidak ada tandingnya di dunia. ${ }^{4}$

Penggunaan bahan peledak dalam penangkapan ikan adalah kegiatan destruktif. Yang apabila dibiarkan secara berlarut larut maka hal ini akan mengancam kelangsungan hidup dan kelestarian ikan, terumbu karang dan biota laut lainnya. Pihak kepolisian yang saat ini mempunyai kewenangan untuk mengatasi hal ini pun mengaku bahwa penanganan

\footnotetext{
${ }^{4}$ Muhamad Erwin, Hukum Lingkungan (Dalam Sistem Kebijakan Pembangunan Lingkungan Hidup), Refika Aditama, Bandung, 2009, hlm 156.
} 
dalam hal penggunaan bahan peledak dalam penangkapan ikan ini bukanlah hal yang mudah. Karena hal ini sudah termasuk budaya atau cara menangkap ikan yang telah lama dilakukan oleh nelayan di Kabupaten Kepulauan Mentawai. Untuk itu perlu strategi strategi khusus dalam menangani hal ini. Dalam hal upaya penanggulangan penggunaan bahan peledak dalam penangkapan ikan di kepulauan mentawai melakukan beberapa upaya yakni upaya preventif dan upaya represif.

Upaya preventif adalah upaya pencegahan yang dilakukan oleh pihak kepolisian untuk mengurangi aktifitas pemboman ikan yang marak dilakukan oleh nelayan khususnya di kepulauan mentawai. Adapun upaya pencegahan yang dilakukan oleh Polres kepulauan mentawai adalah antara lain:

\section{1) Sosialisasi Atau Penyuluhan}

Sosialisasi atau penyuluhan dipusatkan kepada masyarakat di desa desa nelayan yang terindikasi melakukan aktifitas pemboman ikan. Sosialisasi berisikan materi tentang bahaya bom ikan terhadap diri sendiri dan ekosistem laut. Melalui sosialisasi atau penyuluhan ini pihak kepolisian berharap masyarakat di desa desa nelayan yang terindikasi menggunakan bahan peledak dalam menangkap ikan mengetahui tentang bahaya bom ikan tersebut tidak hanya bagi diri sendiri tetapi juga untuk kelestarian dan kelangsungan biota laut. Melalui sosialasi ini juga pihak kepolisian menjelaskan tentang undang undang yang mengatur tentang larangan penggunaan bahan peledak dalam penangkapan ikan yaitu Undang undang Nomor 31 Tahun 2009 tentang Perikanan. Tepatnya pada Pasal 8 dan ketentuan pidananya pada Pasal 84.

2) Melakukan Patroli Rutin

Melakukan patroli yang dilaksanakan kurang lebih 2 kali dalam sebulan dan pada hari hari penting seperti Patroli ini dipusatkan pada nelayan nelayan yang melakukan aktifitas pemboman ikan dan kapal kapal asing yang menyeludupkan pupuk cap matahari sebagai bahan utama dalam pembuatan bom ikan. Dalam hal kegiatan patroli ini, pihak kepolisian mencari tempat tempat yang berpotensi bagi para nelayan pengguna bom ikan serta mendatangi pulau pulau yang disinyalir sebagai tempat para nelayan pengguna bom ikan. Selain itu juga mereka mencari kapal kapal asing yang datang dari luar daerah untuk menjual pupuk cap matahari. Yang berdasarkan informasi mereka melakukan transaksi jual beli itu ditengah laut atau pada pulau pulau yang tersembunyi. Konon, pupuk cap matahari yang diperjual belikan ini adalah hasil seludupan dari negara tetanggan yaitu dari Taiwan dan Malaysia.

Upaya represif yaitu berupa tindakan-tindakan yang dilakukan terhadap para nelayan yang tertangkap tangan menggunakan bahan peledak dalam penangkapan ikan. mereka para nelayan yang tertangkap akan diproses secara hukum dan dikenakan sanksi sesuai dengan ketentuan yang ada. Dari hasil penelitian Penulis Penuntasan kegiatan illegal fishing seperti penggunaan bahan peledak dalam penangkapan ikan, bukanlah sebuah pekerjaan mudah, membutuhkan pola penanganan khusus dengan memberikan pemahaman akan dampak yang diakibatkan kegiatan pengeboman ikan.

Dalam melakukan pengawasan Polres Kepulauan Mentawai tidak bekerja sendirian melainkan bekerja sama dengan instansi-instansi terkait seperti Dinas Perikanan Provinsi Sumbar, TNI Angkatan Udara dan, TNI Angkatan Laut di Provinsi Sumatera barat. Kerjasama dengan berbagai instansi terkait lainnya berguna untuk menggalang 
kemantapan dalam pengawasan jasa kelautan. Hal ini penting dilakukan agar tercapai agar terdapat kesamaan pemahaman dan meningkatkan sinergi antara instansi-instasi terkait.

Pihak Polres Kepulauan Mentawai memiliki tugas yang sangat penting demi terjaganya keamanan wilayah perairan Provinsi Sumatera Barat dari praktek illegal fishing seperti penangkapan ikan dengan menggunakan bahan peledak. Dalam melakukan pengawasan guna memberantas penggunaan bahan peledak dalam penangkapan ikan oleh nelayan melakukan patroli rutin dengan mengunakan kapal-kapal patroli polisi perairan. Kegiatan pengawasan yang dilakukan setiap waktu dan secara berkesinambungan demi terjaganya wilayah perairan di kepulauan mentawai khususnya praktek pengguaan bahan peledak dalam penangkapan ikan yang telah memberikan dampak yang cukup besar bagi pemerintah.

\section{B. Kendala Polres Kepulauan Mentawai Dalam Upaya Penanggulangan Tindak Pidana Penangkapan Ikan Dengan Menggunakan Bahan Peledak}

Tindakan yang dilakukan untuk menanggulangi penangkapan ikan dengan menggunakan bahan peledak, mengalami beberapa hambatan yang sangat mempengaruhi efektivitas tindakan preventif dan represif tersebut. Tindakan preventif yang dilakukan belum mampu membangun kesadaran masyarakat dan belum mampu mencegah secara efektif tindakan penangkapan ikan dengan bahan peledak di wilayah perairan Kabupaten Kepulauan Mentawai. Minimnya tindakan penyuluhan dan pengawasan yang dilakukan Polres Kepulauan Mentawai, sangat berpengaruh terhadap tingkat kesadaran masyarakat dan ketaatan masyarakat terhadap hukum. Penyuluhan dan sosialisasi hanya dilakukan 3 kali dalam setahun dan tidak merata pada seluruh wilayah hukum Polres Kepulauan Mentawai.

Faktor kebutuhan ekonomi dikalangan para nelayan yang didukung oleh kurangnya pengawasan, menjadi alasan bagi masyarakat untuk melakukan tindak pidana penangkapan ikan dengan bahan peledak. Peran tindakan preventif sebenarnya sangat dibutuhkan, karena merupakan solusi kausatif terhadap perilaku tindakan penangkapan ikan yang hampir menjadi budaya di kalangan para nelayan khususnya nelayan yang berasal dari masyarakat tradisional di Kepulauan Mentawai. Penangkapan Ikan dengan bahan peledak sudah dilakukan hampir lebih dari dua generasi. Hal ini selaras dengan pendapat Sadjijono bahwa, oleh karena itu langkah preventif, adalah usaha mencegah bertemunya niat dan kesempatan berbuat jahat, sehingga tidak terjadi kejahatan atau kriminalitas. ${ }^{5}$ Melalui penyuluhan yang rutin sebenarnya akan mampu membangun kesadaran hukum dan kecintaan para nelayan untuk menjaga lingkungan laut.

Pada dasarnya masyarakat nelayan di Kepulauan Mentawai secara umum memiliki siakap dan kepedulian yang positif terhadap upaya pelestarian lingkungan laut (perairan). Namun berkaitan dengan upaya pemenuhan kebutuhan ekonomi, sikap tersebut mulai mengalami pergeseranketika paara nelayan di kepulauan mentawai diahadapkan dengan situasi berupa kekurangan hasil tangkapan ikan dari waktu-kewaktu. Karena terus menurunnya jumlah sumber daya ikan karena banyaknya nelayan dari daerah lain yang

\footnotetext{
${ }^{5}$ Sadjijono, Hukum Kepolisian: Polri dan Good Governance, Laksbang Mediatama, Yogyakarta, 2008, hlm 28
} 
memiliki alat penangkapan ikan yang lebih canggih, sehingga hasil tangkapannya lebih baik dari para nelayan di kepul;auan mentawai, bahkan tidak jarang bnya nelayan dari daerah-daerah lain sekitar kepulauan mentawai yang melakukan penangkapan ikan dengan menggunakan bahan peledak di daerah perairan kepulauan mentawai, hal ini memicu para nelayan di kepulauan mentawai juga melakukan penangkapan ikan dengan menggunakan bahan peledak.

Hanya karena faktor keterbatasan masyarakat nelayan dalam hal pengetahuan dan kepemilikan alat-alat penangkapan ikan yang lebih canggih dan keinginan nelayan untuk mendapatkan hasil tangkapan ikan yang banyak menyebabkan nelayan melakukan penangkapan ikan dengan menggunakan bahan peledak, disamping faktor kesadaran masyarakat nelayan bahwa menangkap ikan dengan menggunakan bahan peledak dapat merusak ekosistem laut.

Kurangnya penyuluhan dan peningkatan pengetahuan masyarakat nelayan di Kepulauan Mentawai menyebabkan banyak diantara masyarakat nelayan di Kepulauan Mentawai tidak mengetahui bahaya yang dapat ditimbulkan dari penggunaan bahan peledak termasuk dampak yang lebih jauh dan tindak pidana penangkap ikan menggunakan bahan peledak terhadap lingkungan. Apabila persoalan ini tidak ditangani secara serius dapat menimbulkan kerugian yang jauh lebih besar bagi kehidupan generasi yang akan datang, diantaranya adalah matinya flora dan fauna laut bersama habitatnya.

Sebagai bukti masih rendahnya tingkat pengetahuan dan kesadaran masyrakt nelayan di kepulauan mentawai terhadap bahaya penggunaan bahan peledak yaitu meskipun sindikat/mata rantai distribusi bom ikan dapat dibongkar ataupun diputus oleh pihak yang berwajib, namun masyrakat nelayan di kepulauan mentawai tidak kehabisan akal, nelayan justru berusaha membuat bahan peledak/bom dngan cara merakitnya sendiri, yang mana hal ini tentunya sangat berbahaya dan beresiko bagi nelayan yang melakukan perakitan bahan peledak itu sendiri.

Apabila dikaji lebih jauh, ternyata yang menjadi motivasi bagi nelayan di kepulauaj mentawai sehingga tetap melakukan kegiatan penangkapan ikan menggunakan bahan peldak adalah untuk menangkap ikan sebanyak-banyaknya dengan cara mudah, murah dan cepat, untuk pemenuhan kebutuhan pokok tanpa memikirkan resiko rusaknya sumber daya ikan di laut.

Proses penyelesaian tindak pidana perikanan juga memiliki beberapa kendala yang mengakibatkan terjadinya tindak pidana penggunaan bahan peledak dalam penangkapan ikan. Proses yang mengalami kendala meliputi pada tahap penyidikan, tahap pra penuntutan, dan tahap penuntutan serta tahap pengenaan sanksi. Di mana pada tahap-tahap tersebut terjadi banyak kendala yaitu di dalam tahap penyidikan ditinjau tentang pengumpulan barang bukti, identifikasi saksi-saksi serta pemberian keterangan tersangka.

Barang bukti memegang peranan penting dalam proses peradilan pidana karena barang bukti adalah barang yang digunakan atau berkaitan langsung dengan tindak pidana. Dengan cukup atau tidaknya barang bukti pada tahap penyidikan akan menetukan perjalanan proses perkara selanjutnya, karena barang bukti dapat berfungsi sebagai alat bukti petunjuk serta digunakan sebagai pelengkap alat bukti keterangan saksi, keterangan tersangka serta alat bukti lain yng diatu dalam KUHAP, sehingga dapat memberikan keyakinan kepada hakim dalam memutus perkara. 
Pada tahun 2019, terdapat 6 (Enam) laporan polisi perihal tindakan pemboman ikan yang ditangani oleh Polres Kepulauan Mentawai dan 1 (satu) laporan polisi yang masih dalam tingkat penyelidikan Polres Kepulauan Mentawai. Sementara itu tahun 2018 terdapat 1 (satu) laporan polisi terkait tindak pemboman ikan yang ditangani Polres Kepulauan Mentawai. Tahun 2017 Polres Kepulauan Mentawai tidak mendapat laporan polisi mengenai tindak pidana pemboman ikan hanya ditemukan 7 (tujuh) perkara melalui patrol yang dilakukan Satpolairud Polres Kepulauan Mentawai. Data tersebut berbeda dengan fakta empiris bahwa masyarakat sering memberikan informasi dan laporan kepada aparat kepolisian perihal adanya tindakan pemboman ikan, namun sejauh ini, Polres Kepulauan Mentawai seringkali tidak melakukan penindakan.

Hal ini disebabkan oleh adanya beberapa hambatan yaitu kurangnya ketersediaan sarana prasarana seperti speedboad yang hanya berjumlah 1 buah dan minimnya biaya operasional untuk kegiatan penangkapan para pelaku pengeboman ikan. Secara kuantitas jumlah personil polisi di Polres Kepulauan Mentawai tidak sebanding dengan kebutuhan di masyarakat.

\section{KESIMPULAN}

Upaya Polres Kepulauan Mentawai dalam penanggulangan tindak pidana penangkapan ikan dengan menggunakan bahan peledak adalah berupa sosialisasi Atau penyuluhan yang dipusatkan kepada masyarakat di desa desa nelayan yang terindikasi melakukan aktifitas penangkapan ikan dengan menggunakan bahan peledak. Sosialisasi berisikan materi tentang bahaya bom ikan terhadap diri sendiri dan ekosistem laut. Melakukan Patroli Rutin yang dilaksanakan kurang lebih 2 kali dalam sebulan dan pada hari hari penting. Patroli ini dipusatkan pada nelayan nelayan yang melakukan aktifitas pemboman ikan dan kapal kapal asing yang menyeludupkan pupuk cap matahari sebagai bahan utama dalam pembuatan bom ikan. Kendala Polres Kepulauan Mentawai dalam upaya penanggulangan tindak pidana penangkapan ikan dengan menggunakan bahan peledak adalah faktor tidak tegasnya penerapan sanksi pidana terhadap pelaku tindak pidana penangkapan ikan dengan menggunakan bahan peledak sering kasus hanya diselesaikan dengan pembuatan surat perjanjian dikarenakan faktor penyebab masyarakat menangkap ikan dengan bahan peledak hanya karena tuntutan ekonomi. Kendala lain adalah Kurangnya kepedulian masyarakat akan lingkungannya terutama lingkungan laut, kurangnya pengetahuan masyarakat nelayan akan dampak penggunaan bahan peledak dalam melakukan penangkapan ikan.

\section{DAFTAR PUSTAKA}

Daliyo et al., Pelestarian Sumber Daya Laut, Partisipasi Dan Kesejahteraan Penduduk Di Kawasan Pesisir, Leusercita Pustaka, Jakarta, 2011.

Supriharyono, Konvensi Ekosistem Sumberdaya Hayati, Cet. ke-1, Pustaka Pelajar, Yogyakarta, 2009

Suharto, Limbah Kimia dalam Pencemaran Udara dan Air, Andi Offset, Yogyakarta, 2011 
Muhamad Erwin, Hukum Lingkungan (Dalam Sistem Kebijakan Pembangunan Lingkungan Hidup), Refika Aditama, Bandung, 2009

Sadjijono, Hukum Kepolisian: Polri dan Good Governance, Laksbang Mediatama, Yogyakarta, 2008 